\title{
Effect of second stage perineal warm compresses on perineal pain and outcome among primiparae
}

\author{
Rasha Mohamed Essa * Nemat Ismail Abdel Aziz Ismail \\ Obstetric and Gynecologic Nursing, Faculty of Nursing, Damnhour University, Damnhour, Egypt
}

Received: August 23, 2015

Accepted: November 26, $2015 \quad$ Online Published: December 14, 2015

DOI: $10.5430 /$ jnep.v6n4p48

URL: http://dx.doi.org/10.5430/jnep.v6n4p48

\begin{abstract}
The aim of this study was to determine the effect of second stage perineal warm compresses on perineal pain and outcome among primiparae. A non-randomized controlled clinical trial was utilized at the labor and delivery unit of National Medical Institution in Damanhour, Albehera Governorate, Egypt. Research was carried out from beginning May 2014 till the end of October 2014, with a total of 160 parturients in their second stage of labor. They were equally randomly divided into study $(\mathrm{N}=80)$ and control $(\mathrm{N}=80)$ groups. Four tools were utilized to collect the necessary data. The first tool was a Socio-demographic and clinical data structured interview schedule. The second tool was a Numerical Pain Rating Score (NPRS), to estimate the subjective level of pain intensity. The third tool was a modified Behavioral Pain Scale (BPS), to measure the behavioral responses to pain. The fourth tool was the second stage and perineal outcome assessment tool: to assess duration of the second stage of labor, mode of delivery, need for pain relief during 2nd stage, baby birth weight, perineal condition, degrees of perineal tear and need to repair. The results revealed that perineal pain intensity did statistically significantly decrease among the study group after the intervention $(P=.000)$. On the other hand, it was slightly increased among the control group after the intervention $(P=.106)$. There was a statistically significant difference between the study and control groups in favor of the former in relation to perineal tear, vaginal tear, degree of perineal tear and need to repair where $P=.000$. The study concluded that second stage perineal warm compresses had better effects on perineal pain and perineal outcome. It resulted in less perineal pain and less genital tract trauma as well as decrease needs to repair. Consequently, it is recommended that perineal warm compresses should be incorporated into pain relief and perineal maintaining options available to women during second stage of labor.
\end{abstract}

Key Words: Second stage of labor, Warm perineal compress, Perineal pain, Perineal trauma

\section{INTRODUCTION}

Each year approximately more than 600,000 women die due to complications related to pregnancy and childbirth. The vast majority of them have been determined to occur in developing countries. Antenatal, natal and postnatal care is among the fundamental protective services for protection and improvement of the health of both mother and the infant to be delivered. ${ }^{[1]}$ Prevention of perineal trauma is one of the best options for birthing women. Accordingly both child-bearing women and health professionals place a high value for minimizing perineal trauma and reducing potential associated morbidity for mothers. ${ }^{[2,3]}$

Trauma to the genital tract is most likely to be present in vaginal birth and is known to be more common in primiparous women. Perineal trauma refers to any damage to the genitalia during childbirth. There are two classification of perineal trauma: Spontaneous perineal trauma which is called nonintentional trauma (tears) and Episiotomy which is called

\footnotetext{
*Correspondence: Rasha Mohamed Essa; Email: rashaessa111@yahoo.com; Address: Obstetric and Gynecologic Nursing, Faculty of Nursing, Damnhour University, Damnhour, Egypt.
} 
intentional trauma. ${ }^{[4]}$ Episiotomy is a deliberate incision made through the perineal body to enlarge the vaginal orifice during birth. While episiotomy only affect the perineal body, which is the area between the vagina and the anus, tears can occur in the labia, vaginal wall, and anterior vaginal structures in addition to the perineal body. ${ }^{[5,6]}$ Perineal tears are classically divided into four categories: 1 st degree: injury to the skin (includes fourchette, hymen, labia, vaginal epithelium); 2nd degree: injury that may involve the posterior vaginal wall, subcutaneous fat, perineal skin layer, superficial muscles, (bulbo-cavernosus and superficial transverse perinei) and deep muscles (pubococcygeus); 3rd degree: this involves disruption of the vaginal pithelium, perineal skin, perineal body and anal sphincter muscles; 4th degree: this involves complete disruption of external and internal anal sphincter complex and the anal epithelium. ${ }^{[7,8]}$

Several risk factors have been established to be associated with the development of severe perineal injuries. Namely, midline episiotomy, fundal pressure, upright delivery postures, prolonged second stage of labor, vaginal operative procedures, and fetal macrosomia. ${ }^{[9,10]}$

Trauma to the genital tract at birth can cause short-term and long-term problems for new mothers. The degree of postnatal morbidity is directly related to the extent and complexity of genital tract trauma. Short-term problems (immediately following birth) include: blood loss, need for suturing, and pain. ${ }^{[11]}$ Genital tract traumas after childbirth also weaken the pelvic floor muscles. Perineal trauma also affects women's physical, psychological, and social wellbeing in the immediate postnatal period as well as in the longer term. Possible deleterious effects include painful intercourse, urinary and fecal incontinence, and persistent perineal pain. ${ }^{[12,13]}$ Where, at 8 weeks after birth, $22 \%$ of new mothers report continued perineal pain, and for some women, pain may persist for a year or longer. ${ }^{[14]}$

Perineal preservation and comfort during the second stage of labor are important goals in the practice of most midwives, as midwives and obstetricians should be aware that perineal trauma is associated with significant short-and long-term morbidity for these finding the ways to improve women's comfort during the second stage would be beneficial. ${ }^{[15]}$ Perineal pain experienced during the second stage of labor can also have an impact on how a woman views her birth experience. Much of the research on pain in labor has focused on the first stage, thus largely overlooking the pain associated with the actual birth. The advancement of the fetal head, and stretching of the perineum in the minutes before giving birth, are accompanied by pain that can be severe. ${ }^{[16]}$

Midwives utilize a variety of non-pharmacological methods in the second stage of labor, in the belief that these may help lower genital tract trauma and perineal pain including: Hands-on or Hands-off,,${ }^{[17,18]}$ perineal massage ${ }^{[19]}$ and warm packs. ${ }^{[15]}$ Perineal warm packs or warm compresses have been advocated for many years in the belief that they reduce perineal trauma and increase comfort during late second stage. ${ }^{[15,16]}$

Many studies were carried out to assess effect of second stage perineal warm compresses on perineal pain and trauma. Lydon-Rochelle (1995) ${ }^{[20]}$ had carried a retrospective, non randomized cohort study of 1,211 women, comparing birth positions and management of the perineum (including hot compresses, water-based lubricants, perineal support or massage) with perineal lacerations or midline episiotomy. This study had revealed that perineal hot compresses and lubricant increased lacerations, while support and massage had no effect. Both primiparous and multiparous women were included in this study.

Another observational cohort study done by Albers et al. $(1996)^{[21]}$ found that warm compresses, flexion of the fetal head, and lateral birth position were associated with a decrease in perineal trauma, while oils, lubricants, lithotomy position and epidural anaesthesia were associated with increased perineal trauma. The next study was conducted in 1998 by Murphy \& Feinland, who concluded that the use of warm compresses appeared to increase the perineal trauma in multiparous women, while in primiparous women they had no effect. ${ }^{[22]}$ In addition, Musgrove (1999) ${ }^{[23]}$ conducted the first randomized controlled trial in Australia about the use of warm packs on the perineum. The study was small, involving 71 women having their second normal vaginal delivery. In the experimental group, $70 \%$ of women did not require suturing compared to $54 \%$ in the control group, which was statistically significant. Pain was also reduced and $80 \%$ of the women reported gaining comfort from the warm packs. The sample size in this study was small and restricted to multigravid women, limiting generalisability.

Furthermore, a Cochrane review of the literature surrounding management of perineal trauma confirms the benefit of warm compresses during second stage. This method is available at every birth, non-invasive, inexpensive, causes no harm and women find it comfortable. ${ }^{[24]}$ A recent randomized clinical trial study showed that using warm compress in the second stage of delivery can decrease perineal trauma and relief of pain in this stage. ${ }^{[25]}$

Midwives have traditionally taken pride in the fact that they are able to improve a woman's chance of having an intact perineum. It is important to identify the methods, which may be unique to midwifery practice, that are responsible 
for these outcomes. They need to base their practice on evidence in order to offer the best care possible and to play an active role in the health care system. The evidence regarding the perineal warm compresses to reduce perineal pain and trauma during the second stage of labor remains contradictory. Therefore this study was aimed to determine the effect of second stage perineal warm compresses on perineal pain and outcome among primiparae.

\subsection{Objective}

This study was aimed to determine the effect of second stage perineal warm compresses on perineal pain and outcome among primiparae.

\subsection{Hypothesis}

Laboring women who receive second stage perineal warm compresses experience less perineal pain and less genital tract trauma as well as less need to repair than those who receive routine hospital care.

\subsection{Operational definitions}

Perineal outcome: In this study refers to perineal condition (intact, episiotomy or tears), degrees of perineal tear and need to repair.

\section{MATERIAL AND METHODS}

A non randomized controlled clinical trial was utilized at the labor and delivery unit of National Medical Institution in Damanhour, Albehera Governorate. The study comprised a convenience sample of 160 parturients in their second stage of labor based on the program of Epi-Info which was used to estimate the sample size using the following parameters:

(1) Target population 200 per 3 months;

(2) Expected frequency $=50 \%$;

(3) Acceptable error $=5 \%$;

(4) Confidence coefficient $=99 \%$;

(5) Sample size $=160$;

(6) Power analysis $=80 \%$.

The study subjects enrolled in this study according to the following inclusion criteria: aged from 18-35 years, primigravida, had normal pregnancy, had a singleton pregnancy with a cephalic presentation, full term, no contraindications for vaginal delivery, they had not performed perineal massage and willing to participate in the study.

The study subjects were randomly assigned in a 1:1 ratio to study and control groups. Randomization had occurred upon confirmation of full dilatation of the cervix at which point the parturient was asked to select one closed envelope from a set of 160 . The envelope had contained a card with the groups' allocation (study or control groups).
The study group (warm compresses group) had received usual care during labor until the second stage of labor then warm perineal compress were applied by the researchers to the women's perineum during the whole second stage of labor. The applied warm perineal compress was carried out as follow: A sterile metal container was filled with warm water $\left(45^{\circ} \mathrm{C}-59^{\circ} \mathrm{C}\right)$ then a sterile towel was soaked in the water and squeezed before being placed gently on the perineum during each uterine contraction. The temperature ranged from $38^{\circ} \mathrm{C}$ to $44^{\circ} \mathrm{C}$ during its application. Between contractions, the towel was re-soaked in the water to maintain warmth then reapplied again. The water in the metal container was replaced every 15 minutes until delivery or if the temperature dropped below $45^{\circ} \mathrm{C} .^{[23]}$

The control group had received the routine hospital care during the second stage of labor that was defined as any second stage practice carried out by midwives that did not include the application of warm compresses to the perineum.

\section{Tools of data collection}

Four tools were utilized to collect the necessary data. The tools were either developed or modified after reviewing relevant literature, and checked for content validity by a jury of 7 experts in the field. Tools' reliability was assessed by having the two researchers watching the second stage of labor for 16 cases in a pilot study simultaneously, and independently recording data according to the tools' instructions. The data was then used to compute an index of equivalence or agreement between researchers. The association between the two researchers' ratings of percentage was estimated using Pearson's correlation. This association was high, where $r=0.93$ $\& P=.001$.

\section{Tool (I): Socio-demographic and clinical data structured interview schedule}

It was developed by the researchers to collect the following data:

(1) Socio-demographic data such as age, level of education, occupation, current residence, and family income/month.

(2) Reproductive history such as weeks of gestation, number of antenatal care.

(3) Anthropometric measurements such as height and weight to calculate body mass index (BMI).

\section{Tool (II): Numerical Pain Rating Score (NPRS)}

It was adapted from McCaffery and Pasero (1999). ${ }^{[26]}$ It is a standardized self-report device consisting of a horizontal line used to estimate the subjective level of pain intensity. It comprises 10 point numerical scale, corresponding to the degree of pain with zero representing no pain and 10 representing 
the worst degree of pain. In between these two opposite ends, words as mild, moderate, severe and very severe pain are assigned to each $2 \mathrm{~cm}$ distance, respectively.

\section{Tool (III): A modified Behavioral Pain Scale (BPS)}

It is used to measure the behavioral responses to pain. It includes four dimensions: tense muscle, restlessness, grimacing and patient sounds. For each of these four major behavioral responses one of a four alternative choices were elicited by the researchers. For tense muscle, the choice is between relaxed muscles or slightly tense or moderate tense or severe tense. For restlessness, the choice is between quiet, slightly restless or moderate restless or very restless. For grimacing the choice is between no grimacing, some grimacing or moderate grimacing or constant grimacing. Finally, parturient's sounds varied between normal sounds, groans/moans or Groans/moans loudly and cry out or sobs. ${ }^{[27]}$

\section{Tool (IV): Assessment tool on second stage and perineal outcome}

It included assessment of duration of the second stage of labor, mode of delivery, need for pain relief during 2nd stage, baby birth weight, perineal condition, degrees of perineal tear and need to repair.

Data of Tool (I) were collected from both groups through an interview schedule, which was conducted individually and in total privacy. Each study subject was interviewed for 5-10 minutes during the first stage of labor, during this time anthropometric measurements (height and weight) were carried out to calculate BMI. Tool (II) and (III) were used to assess the intensity of women's pain and behavioral responses to pain for both (study \& control group) immediately before the application of perineal warm compresses upon fully cervical dilatation at the beginning of the second stage of labor. The researchers, stayed with each woman until the end of the second stage of labor during this time warm perineal compresses were applied by the researchers to the women's perineum for study group only during the whole second stage of labor. Then, pain was, reassessed through the same tools (II and III) for each woman in both groups immediately after birth. Tool (IV) was used for both groups immediately following the second stage of labor to assess duration of the second stage of labor, mode of delivery, need for pain relief, baby birth weight, perineal condition, degrees of perineal tear and need to repair.

An official letter from the Faculty of Nursing, Damanhour University was directed to the responsible authorities to obtain their permission to conduct the study after explaining its aim. Purpose of the study was explained to each women and an oral consent for participation in the study was obtained. Those who agreed to participate were assured about confidentiality, privacy and their right to withdraw from the study at any time. A pilot study was carried out on 16 laboring women (who were excluded from the study sample) to ascertain the clarity and the applicability of the tools

The study was conducted over a period of 6 months beginning May 2014 till the end of October 2014. Statistical analysis was done after collection of data by using Statistical Package for Social Sciences (SPSS) version 16. Descriptive and analytical statistics were used such as percentages, means and standard deviations. Chi-square-test, Fisher Exact-test, and $T$-test with a $P$ value was set at .05 to identify statistical significance difference between the results.

\section{Results}

Table 1 indicates absence of any significant differences between the study and control groups in their general characteristics, number of antenatal visits and body mass index. Where about one-third (32.5\% and 37.5\%) among the study and control groups, respectively were less than twenties. Illiteracy was evident among close proportions of the study and control group (30\% and $32.5 \%$ respectively). More than three-fifths $(62.5 \%)$ of the study group were from urban area compared to three quarters $(75 \%)$ of the control group. The majority of the study and control groups (85\% and $77.5 \%$, respectively) were housewives, and had 4 antenatal visits or more $(77.5 \%$ and $70 \%$, respectively). More than three-fifths (70\% and $62.5 \%$ ) among the study and control groups, respectively had just enough family income. Mean Body mass index was evident in close proportion among the study and control groups, respectively $(27.77 \pm 1.109$ and $28.04 \pm$ 1.202) respectively.

Table 2 shows the distribution of the study subjects according to their labor pain intensity-measured by visual analogue scale (VAS)-before and after the intervention. It is obvious that pain intensity did statistically significantly decreased among the study group after the intervention $(P=.000)$. On the other hand, it was slightly increased among the control group after the intervention $(P=.106)$. The difference between the two groups-in this respect-was statistically significant $(P=.000)$. Specifically, almost two-thirds $(62.5 \%)$ of the study group had severe pain before the intervention and only $10 \%$ of them reported such pain response after the intervention. This is compared to one-half (57.5\%) and $65 \%$ of the control group who suffered severe pain before and after the intervention respectively. Moreover, $17.5 \%$ of the study group had experience unbearable pain before the intervention. While none of them had such pain intensity after the intervention. This is compared with $10 \%$ and $15 \%$ of the control group who had experienced such an unbearable pain before and after the intervention, respectively. 
Table 1. Number, percent and mean distribution of study subjects according to their socio-demographic and obstetric data

\begin{tabular}{|c|c|c|c|c|c|}
\hline \multirow{2}{*}{ Socio-demographic and obstetric data } & \multicolumn{2}{|c|}{ Study group $=\mathbf{8 0}$} & \multicolumn{2}{|c|}{ Control group $=\mathbf{8 0}$} & \multirow{2}{*}{$\mathrm{FET} / \chi^{2}(P)$} \\
\hline & No & $\%$ & No & $\%$ & \\
\hline \multicolumn{6}{|l|}{ Age (years) } \\
\hline$<20$ & 26 & 32.5 & 30 & 37.5 & \multirow{3}{*}{$1.971(.373)$} \\
\hline $20-30$ & 40 & 50.0 & 42 & 52.5 & \\
\hline$\geq 30$ & 14 & 17.5 & 8 & 10.0 & \\
\hline \multicolumn{5}{|l|}{ Level of education } & \multirow{5}{*}{$3.148(.369)$} \\
\hline Illiterate/read \& write & 24 & 30.0 & 26 & 32.5 & \\
\hline Primary/preparatory & 20 & 25.0 & 26 & 32.5 & \\
\hline Secondary & 30 & 37.5 & 20 & 25.0 & \\
\hline University & 6 & 07.5 & 8 & 10.0 & \\
\hline \multicolumn{5}{|l|}{ Occupation } & \multirow{3}{*}{$1.477(.224)$} \\
\hline Housewife & 68 & 85.0 & 62 & 77.5 & \\
\hline Working & 12 & 15.0 & 18 & 22.5 & \\
\hline \multicolumn{5}{|l|}{ Current residence } & \multirow{3}{*}{$2.909(.088)$} \\
\hline Urban & 50 & 62.5 & 60 & 75.0 & \\
\hline Rural & 30 & 37.5 & 20 & 25.0 & \\
\hline \multicolumn{5}{|l|}{ Family income/month } & \multirow{4}{*}{$2.194(.334)$} \\
\hline More than enough & 6 & 07.5 & 4 & 05.0 & \\
\hline Just enough & 56 & 70.0 & 50 & 62.5 & \\
\hline Not enough & 18 & 22.5 & 26 & 32.5 & \\
\hline \multicolumn{5}{|l|}{ Number of antenatal visits } & \multirow{3}{*}{$1.162(.281)$} \\
\hline$<4$ & 18 & 22.5 & 24 & 30.0 & \\
\hline$\geq 4$ & 62 & 77.5 & 56 & 70.0 & \\
\hline Body mass index (BMI) & \multicolumn{2}{|c|}{$27.77 \pm 1.109$} & \multicolumn{2}{|c|}{$28.04 \pm 1.202$} & $\begin{array}{l}T(P) \\
1.490(.138)\end{array}$ \\
\hline
\end{tabular}

Note. $\chi^{2}(P)$ : Chi-Square Test $\& P$ for $\chi^{2}$ Test; FET $(P)$ : Fisher Exact Test $\& P$ for FET-Test; $T(P): T$-test $\& P$ for $T$-test.

Table 2. Number and percent distribution of the study subjects according to their perineal pain intensity before and after the intervention

\begin{tabular}{|c|c|c|c|c|c|c|c|c|c|c|}
\hline \multirow{3}{*}{$\begin{array}{l}\text { Pain intensity } \\
\text { (VAS) }\end{array}$} & \multicolumn{4}{|c|}{ Study group $=\mathbf{8 0}$} & \multicolumn{4}{|c|}{ Control group $=\mathbf{8 0}$} & \multirow{3}{*}{$\begin{array}{l}\text { FET } / \chi^{2} \\
(P) \\
\text { Before }\end{array}$} & \multirow{3}{*}{$\begin{array}{l}\text { FET } / \chi^{2} \\
(P) \\
\text { After }\end{array}$} \\
\hline & \multicolumn{2}{|c|}{$\begin{array}{l}\text { Before } \\
\text { intervention }\end{array}$} & \multicolumn{2}{|c|}{$\begin{array}{l}\text { After } \\
\text { intervention }\end{array}$} & \multicolumn{2}{|c|}{$\begin{array}{l}\text { Before } \\
\text { intervention }\end{array}$} & \multicolumn{2}{|c|}{$\begin{array}{l}\text { After } \\
\text { intervention }\end{array}$} & & \\
\hline & No. & $\%$ & No. & $\%$ & No. & $\%$ & No. & $\%$ & & \\
\hline -Mild 1-3 & 2 & 02.5 & 20 & 25.0 & 4 & 05.0 & 0 & 0.00 & & \\
\hline - Moderate 4-6 & 14 & 17.5 & 52 & 65.0 & 22 & 27.5 & 16 & 20.0 & 4.187 & 93.030 \\
\hline - Severe 7-9 & 50 & 62.5 & 8 & 10.0 & 46 & 57.5 & 52 & 65.0 & $(.235)$ & $(.000)^{*}$ \\
\hline - Unbearable $\geq 10$ & 14 & 17.5 & 0 & 0.00 & 8 & 10.0 & 12 & 15.0 & & \\
\hline $\mathrm{FET} / \chi^{2}(P)$ & \multicolumn{4}{|c|}{$81.02(.000)^{*}$} & \multicolumn{4}{|c|}{$6.115(.106)$} & & \\
\hline
\end{tabular}

Note. $\chi^{2}(P)$ : Chi-Square Test \& $P$ for $\chi^{2}$ Test; FET $(P)$ : Fisher Exact Test $\& P$ for FET-Test; *: Significant at $P \leq .05$.

Table 3 presents number and percent distribution of the study subjects according to their behavioral responses to labor pain before and after the intervention. Among the study group, the table clearly illustrates a statistically significant differences regarding all parameters of behavioral responses as presented by tense muscles, restlessness, grimacing and patient sounds before and after the intervention among the study group where $(P=.000)$. Where severe tense was observed among $50 \%$ of them before the intervention then these percent decreased to $7.5 \%$ after the intervention. Very restlessness decreased from $47.5 \%$ to $10 \%$ after the intervention. Constant grimacing, it was greatly decreased after the intervention (from $50 \%$ to $12.5 \%$ ). Groans/moans loudly and cry out were decreased from $55 \%$ and $32.5 \%$ respectively to $10 \%$ and $7.5 \%$ respectively after the intervention. On the contrary, in relation to the control group, the table also reveals that, no significant change was observed within the control group in relation to the same parameters of behavioral responses. 
However, the differences between the study and the control in relation to the same parameters of behavioral responses, groups after intervention were statistically highly significant where $P=.000$.

Table 3. Number and percent distribution of the study subjects according to their behavioral responses before and after the intervention

\begin{tabular}{|c|c|c|c|c|c|c|c|c|c|c|}
\hline \multirow{3}{*}{ Behavioral responses } & \multicolumn{4}{|c|}{ Study group $=80$} & \multicolumn{4}{|c|}{ Control group $=\mathbf{8 0}$} & \multirow{3}{*}{$\begin{array}{l}\text { FET } / \chi^{2} \\
(P) \\
\text { Before }\end{array}$} & \multirow{3}{*}{$\begin{array}{l}\text { FET } / \chi^{2} \\
(P) \\
\text { After }\end{array}$} \\
\hline & \multicolumn{2}{|c|}{$\begin{array}{l}\text { Before } \\
\text { intervention }\end{array}$} & \multicolumn{2}{|c|}{$\begin{array}{l}\text { After } \\
\text { intervention }\end{array}$} & \multicolumn{2}{|c|}{$\begin{array}{l}\text { Before } \\
\text { intervention }\end{array}$} & \multicolumn{2}{|c|}{$\begin{array}{l}\text { After } \\
\text { intervention }\end{array}$} & & \\
\hline & No. & $\%$ & No. & $\%$ & No. & $\%$ & No. & $\%$ & & \\
\hline \multicolumn{11}{|l|}{ Tense muscle } \\
\hline -Relaxed muscles & 0 & 00.0 & 8 & 10.0 & 0 & 00.0 & 0 & 00.0 & \multirow{5}{*}{$\begin{array}{l}0.491 \\
(.782)\end{array}$} & \multirow{5}{*}{$\begin{array}{l}78.526 \\
(.000)^{*}\end{array}$} \\
\hline -Slightly tense & 14 & 17.5 & 52 & 65.0 & 12 & 15.0 & 6 & 07.5 & & \\
\hline -Moderate tense & 26 & 32.5 & 14 & 17.5 & 30 & 37.5 & 32 & 40.0 & & \\
\hline -Severe tense & 40 & 50.0 & 6 & 07.5 & 38 & 47.5 & 42 & 52.5 & & \\
\hline $\mathrm{FET} / \chi^{2}(P)$ & \multicolumn{4}{|c|}{$58.609(.000)^{*}$} & \multicolumn{4}{|c|}{$2.265(.322)$} & & \\
\hline \multicolumn{11}{|l|}{ Restlessness } \\
\hline -Quiet & 0 & 00.0 & 10 & 12.5 & 0 & 00.0 & 0 & 00.0 & \multirow{5}{*}{$\begin{array}{l}1.007 \\
(.604)\end{array}$} & \multirow{4}{*}{$\begin{array}{l}68.102 \\
(.000)^{*}\end{array}$} \\
\hline -Slightly restless & 18 & 22.5 & 46 & 57.5 & 16 & 20.0 & 8 & 10.0 & & \\
\hline -Moderate restless & 24 & 30.0 & 16 & 20.0 & 30 & 37.5 & 22 & 27.5 & & \\
\hline -Very restless & 38 & 47.5 & 8 & 10.0 & 34 & 42.5 & 50 & 62.5 & & \\
\hline $\mathrm{FET} / \chi^{2}(P)$ & \multicolumn{4}{|c|}{$43.415(.000)^{*}$} & \multicolumn{4}{|c|}{$6.945(.031)$} & & \\
\hline \multicolumn{11}{|l|}{ Grimacing } \\
\hline -No grimacing & 0 & 00.0 & 10 & 12.5 & 0 & 00.0 & 0 & 00.0 & \multirow{5}{*}{$\begin{array}{l}1.011 \\
(.603)\end{array}$} & \multirow{5}{*}{$\begin{array}{l}60.933 \\
(.000)^{*}\end{array}$} \\
\hline -Some grimacing & 16 & 20.0 & 50 & 62.5 & 20 & 25.0 & 12 & 15.0 & & \\
\hline -Moderate grimacing & 24 & 30.0 & 10 & 12.5 & 26 & 32.5 & 22 & 27.5 & & \\
\hline -Constant grimacing & 40 & 50.0 & 10 & 12.5 & 34 & 42.5 & 46 & 57.5 & & \\
\hline $\mathrm{FET} / \chi^{2}(P)$ & \multicolumn{4}{|c|}{$51.28(.000)^{*}$} & \multicolumn{4}{|c|}{$4.133(.127)$} & & \\
\hline \multicolumn{11}{|l|}{ Patient sounds } \\
\hline -Normal sound & 0 & 00.0 & 16 & 20.0 & 0 & 00.0 & 0 & 00.0 & \multirow{5}{*}{$\begin{array}{l}1.764 \\
(.414)\end{array}$} & \multirow{5}{*}{$\begin{array}{l}85.655 \\
(.000)^{*}\end{array}$} \\
\hline -Groans/moans & 10 & 12.5 & 50 & 62.5 & 16 & 20.0 & 8 & 10.0 & & \\
\hline -Groans/moans loudly & 44 & 55.0 & 8 & 10.0 & 42 & 52.5 & 46 & 57.5 & & \\
\hline -Cry out or sobs & 26 & 32.5 & 6 & 07.5 & 22 & 27.5 & 26 & 32.5 & & \\
\hline $\mathrm{FET} / \chi^{2}(P)$ & \multicolumn{4}{|c|}{$80.09(.000)^{*}$} & \multicolumn{4}{|c|}{$3.182(.204)$} & & \\
\hline
\end{tabular}

Note. $\chi^{2}(P)$ : Chi-Square Test $\& P$ for $\chi^{2}$ Test; *: Significant at $P \leq .05$.

According to Table 4, a statistically significant difference was observed between both groups only in relation to the need for pain relief during 2 nd stage where $(P=.000)$. Only $7 \%$ of the study group needed pain relief during 2 nd stage compared to more than two fifths (45\%) of the control group. On the other hands, no significant difference was observed between both groups regarding mode of delivery, mean duration of the second stage, and mean baby birth weight. The majority $(92.5 \%$ and $87.5 \%)$ of the study group and control group, respectively, had vaginal delivery. Mean duration of the second stage was $(81.150 \pm 6.585)$ among the study group compared to $(82.425 \pm 6.710)$ for control group. In addition, Mean baby birth weight among the study and control groups were ( $3.003 \pm 0.120$ and $2.964 \pm 0.135)$ respectively.

Table 5 shows the number and percent distribution of the study subjects according to their genital tract trauma. It was observed that more than three-fifths $(62.5 \%)$ of the study group had an intact perineum compared to only $2.5 \%$ of the control group. Most (95\% and $97.5 \%$ ) of the study group did not had either vaginal or perineal tear respectively compared to $(65 \%$ and $68.7 \%)$ of the control group. Among those who had perineal tear, it was found that, third degree perineal tear was found in about one half (48\%) of control group compared to no one of the study group. Slightly less than one third $(32.5 \%)$ of the study group their genital tract trauma need to repair compared to the most $(97.5 \%)$ of the control group. On the other hands, most of the study and control groups (97.5\% and $92.5 \%$, respectively) did not have labial tear. There was a statistically significant difference between the study and control groups in favor of the former in relation to perineal condition, vaginal tear, degree of perineal tear and need to repair where $P=.000$. 
Table 4. Number, percent and mean distribution of study subjects according to their second stage characteristics and babies' birth weight

\begin{tabular}{|c|c|c|c|c|c|}
\hline \multirow{2}{*}{ Second stage characteristics and babies' birth weight } & \multicolumn{2}{|c|}{ Study group $=\mathbf{8 0}$} & \multicolumn{2}{|c|}{ Control group $=\mathbf{8 0}$} & \multirow{2}{*}{ FET $/ \chi^{2}(P)$} \\
\hline & No & $\%$ & No & $\%$ & \\
\hline \multicolumn{5}{|l|}{ Mode of delivery } & \multirow{3}{*}{$\begin{array}{l}1.111 \\
(.292)\end{array}$} \\
\hline Normal & 74 & 92.5 & 70 & 87.5 & \\
\hline Forceps & 6 & 07.5 & 10 & 12.5 & \\
\hline \multicolumn{5}{|l|}{ Need for pain relief during 2 nd stage } & \multirow{3}{*}{$\begin{array}{l}34.133 \\
(.000)^{*}\end{array}$} \\
\hline Yes & 6 & 07.5 & 36 & 45.0 & \\
\hline No & 74 & 92.5 & 44 & 55.0 & \\
\hline \multicolumn{3}{|l|}{ Duration of the 2nd stage (min) } & \multirow{2}{*}{\multicolumn{2}{|c|}{$82.425 \pm 6.710$}} & \multirow{2}{*}{$\begin{array}{l}1.221 \\
(.224)\end{array}$} \\
\hline Mean \pm SD & 81.1 & .585 & & & \\
\hline \multicolumn{3}{|l|}{ Baby birth weight (g) } & \multirow{2}{*}{\multicolumn{2}{|c|}{$2.964 \pm 0.135$}} & 1.916 \\
\hline Mean \pm SD & \multicolumn{2}{|c|}{$3.003 \pm 0.120$} & & & $(.057)$ \\
\hline
\end{tabular}

Note. $\chi^{2}(P)$ : Chi-Square Test $\& P$ for $\chi^{2}$ Test; FET $(P)$ : Fisher Exact Test $\& P$ for FET-Test; $T(P): T$-test $\& P$ for $T$-test; *: Significant at $P \leq .05$.

Table 5. Number and percent distribution of the study subjects according to their perineal outcome

\begin{tabular}{|c|c|c|c|c|c|}
\hline \multirow{2}{*}{ Perineal outcome } & \multicolumn{2}{|c|}{ Study group $=80$} & \multicolumn{2}{|c|}{ Control group $=\mathbf{8 0}$} & \multirow{2}{*}{ FET $/ \chi^{2}(P)$} \\
\hline & No & $\%$ & No & $\%$ & \\
\hline \multicolumn{6}{|l|}{ Perineal condition } \\
\hline -Intact & 50 & 62.5 & 2 & 02.5 & \multirow{3}{*}{$\begin{array}{l}69.887 \\
(.000)^{*}\end{array}$} \\
\hline -Episiotomy & 26 & 32.5 & 50 & 62.5 & \\
\hline -Tear & 4 & 05.0 & 28 & 35.0 & \\
\hline \multicolumn{5}{|l|}{ Vaginal tear } & \multirow{3}{*}{$\begin{array}{l}22.5 \\
(.000)^{*}\end{array}$} \\
\hline -Yes & 4 & 05.0 & 28 & 35.0 & \\
\hline$-\mathrm{No}$ & 76 & 95.0 & 52 & 65.0 & \\
\hline \multicolumn{6}{|l|}{ Labial tear } \\
\hline -Yes & 2 & 02.5 & 6 & 07.5 & \multirow{2}{*}{$\begin{array}{l}2.105 \\
(.277)\end{array}$} \\
\hline -No & 78 & 97.5 & 74 & 92.5 & \\
\hline \multicolumn{5}{|l|}{ Perineal tear } & \multirow{3}{*}{$\begin{array}{l}23.57 \\
(.000)^{*}\end{array}$} \\
\hline -Yes & 2 & 02.5 & 25 & 31.3 & \\
\hline -No & 78 & 97.5 & 55 & 68.7 & \\
\hline \multicolumn{3}{|l|}{ Degrees of perineal tear } & \multicolumn{2}{|l|}{$\mathrm{n}=25$} & \multirow{5}{*}{$\begin{array}{l}10.781 \\
(.003)^{*}\end{array}$} \\
\hline -First & 2 & 100.0 & 0 & 0.00 & \\
\hline -Second & 0 & 0.00 & 9 & 36.0 & \\
\hline -Third & 0 & 0.00 & 12 & 48.0 & \\
\hline -Fourth & 0 & 0.00 & 4 & 16.0 & \\
\hline \multicolumn{3}{|l|}{ Need to repair } & & & \multirow{3}{*}{$\begin{array}{l}74.286 \\
(.000)^{*}\end{array}$} \\
\hline -Yes & 26 & 32.5 & 78 & 97.5 & \\
\hline -No & 54 & 67.5 & 2 & 02.5 & \\
\hline
\end{tabular}

Note. $\chi^{2}(P)$ : Chi-Square Test $\& P$ for $\chi^{2}$ Test; FET $(P)$ : Fisher Exact Test $\& P$ for FET-Test; *: Significant at $P \leq .05$.

\section{Discussion}

In view of the magnitude of perineal morbidity, interventions which aid in the reduction of perineal trauma and perineal discomfort are desirable. Different perineal techniques and interventions are being used to slow down the birth, and allow the perineum to stretch slowly to prevent perineal injury. Perineal massage, warm compresses and different perineal management techniques are widely used by midwives and birth attendants. The application of perineal warm compresses is widely advocated by midwives to reduce perineal trauma and improve comfort during second stage of labor. ${ }^{[24,28]}$

The present study reveled that perineal pain intensity had decreased after the application of warm compresses among the study group $(P=.000)$. Meanwhile, such a decrease was not observed among the control group after received routine hospital care $(P=.106)$. This may be explained by the possi- 
bility that the warm compresses somehow altered connective tissue in a superficial level leading to fewer small splits and grazes, all of which may contribute to overall decreased levels of pain. It is also possible that the utilization of perineal warm compresses had minimized midwives' perineal touch leading to less bruises.

The present result is similar to the results of Dahlen et al. $(2007)^{[29]}$ who did investigate the reduction of perineal trauma and improved perineal comfort during and after childbirth: the Perineal Warm Pack Trial. They had reported a significant reduction in pain among their study group (application of the warm perineal packs) at birth and at day one, compared to control group (the standard care group who received routine hospital care) without application of the warm perineal packs. In addition, this finding is also in agreement with the results of another study done by Behmanesh et al. $(2009)^{[30]}$ who did a study about the effect of heat therapy on labor pain severity and delivery outcome in parturient women. They found that the pain severity in the heat therapy group was less than that in the control group in the first and second labor stages. Also, heat therapy caused reduction in labor pain. Ahmad and Turky (2010) ${ }^{[31]}$ also concluded that the application of warm perineal packs had potential benefits on decreasing the level of perineal pain immediately after birth and on day one following birth. Moreover, the present finding is in accordance with that of Mamuk and Gençalp (2013) who had found a significantly lower in perineal pain among the study group. ${ }^{[32]}$

Such similarities among the present study results and those of the above mentioned ones could be attributed to what is elicited in the literature about the positive therapeutic effects that heat produces. Heat dilates blood vessels and increases blood flow, it can influence the transmission of pain impulses and increase collagen extensibility: Overall an increase in local circulation can reduce the level of nociceptive stimulation by reducing local ischaemia caused by muscle spasm or tension, it can increase the removal of metabolites and inflammatory mediators that act as nociceptive stimuli and it can help to reduce swelling and relieve pressure on local nociceptive endings. It may also produce the release of endogenous opiates through placebo-type mechanisms. ${ }^{[33,34]}$

Moreover, according to the Midwifery texts which also describe the effects of heat when recommending its use as a nonpharmacological physical comfort measure: Heat increases local skin temperature, circulation, and tissue metabolism. It reduces muscle spasm and raises the pain threshold. Heat also reduces the fight or flight response (as evidenced by trembling and "goose pimples"). Local heat to a warm blanket calms the woman, and also may increase her receptivity to a stroking type of massage which she cannot tolerate when her skin is sensitive or sore due to the fight or flight response. ${ }^{[35]}$

Women behavioral responses to perineal pain did decrease among the study group after the application of perineal warm compresses. In this study the framework for the behavioral assessment was based on the modified behavioral pain scale. This assessment is based on the fact that laboring women are always irritable and tense. Consequently, such tension shapes their pain response resulting in certain body movements related to tense muscle, restlessness, grimacing and patient sounds.

Tense muscle is the most important cue for pain assessment; it can confirm the presence of pain. In the present study, severe tense muscles-among the study group-had decrease from $50 \%$ to $7.5 \%$ after the application of perineal warm compresses. This finding can suggest that perineal warm compresses can enhance relaxation, reduce muscle spasm and reduce pain during labor. Warm compress may cause vasodilatation of blood vessels which can increase blood flow in the tissue around the area that is compressed so that the decreasing of ischemia tissue and pain can be reduced. ${ }^{[36]}$

Again, as expected, restlessness did also decrease from $47.5 \%$ to $10 \%$ among the study group after the application of perineal warm compresses. Restlessness is defined as "inability to get the comfort position". When the intensity of pain was decreased the women became more calm and quite. Grimacing had also changed among the study group where constant grimacing was decreased from $50 \%$ to $12.5 \%$ after the application of perineal warm compresses. The present study also revealed that groans/moans loudly and cry out or sobs are significantly decrease after the application of perineal warm compresses among the study group. These results were expected since a woman's pain intensity had decreased after the application of perineal warm compresses (see Table 2) which lead to enhance women's comfort, and increase their orientation as well as coping with pain.

Most vaginal births are associated with some form of trauma to the genital tract. The morbidity associated with perineal trauma is significant, especially when it comes to third- and fourth-degree tears. The present study results revealed a significant decreased in the incidence of episiotomy and tear (vaginal and perineal tears) among the study group where $(P=.000)$. This finding may reflect the benefit of applying warm compresses on the perineum during the second stage of labor.

The results of the present study agree with the results of at least five other researches. The first Hastings-Tolsma et al. (2007) ${ }^{[37]}$ who had done a study titled getting through 
birth in one piece: protecting the perineum. They found that warm moist compresses applied during second stage of labor were protective of the perineum. In addition, the presence of the warm pack on the perineum made touching the perineum less harming leading to less bruising. The Second, Dahlen et al. (2009) ${ }^{[38]}$ who had done a study titled "Soothing the ring of fire": It investigated the Australian women's and midwives experiences of using perineal warm packs in the second stage of labor. They are reported that there are reasonable data to support the use of warm compresses. It showed a reduction in severe perineal trauma and also other benefits, such as reduced pain and reduced incidence of urine incontinence, absence of harm and cheap. The second further elaborated that the procedure has been shown to be acceptable to both women and midwives. The third, Mohamed et al. (2011) ${ }^{[39]}$ who found that the use of warm pack in the perineum during the expulsive period does reduce the occurrence of perineal laceration. These results support the use of perineal warm compresses techniques by trained birth attendants. The fourth, Aasheim et al. (2012) ${ }^{[24]}$ who had studied perineal techniques during the second stage of labor for reducing perineal trauma. They found from their meta-analyses that there was a significant effect of the use of warm compresses compared with hands off or no warm compress on the incidence of third and fourth degree tears. They also concluded that women should be offered warm compresses as their use may reduce perineal trauma and the intervention is acceptable to both women and midwives. The fifth, Dahlen et al. (2015) ${ }^{[40]}$ who concluded in their recent study that Warm compresses should be offered to women as second stage comfort and due to the fact they are associated with a reduction in severe perineal trauma (45\%) and are acceptable to women and midwives.

On the other hand, the same result contradicts to the findings of Albers et al. (2005). ${ }^{[41]}$ They had studied the midwifery care measures in the second stage of labor and reduction of genital tract trauma at birth. Their results had revealed that warm compresses or massage with lubricant provide no apparent advantage or disadvantage in reducing genital tract trauma, when compared with keeping hands off the perineum late in the second stage of labor. They rationalized their results by several factors, first, their study setting may be unusual in that episiotomy and vaginal operative procedures are rarely performed by any care providers. This allowed spontaneous lacerations to be a relatively pure focus of the study. Second, the 12 midwives who performed this study already have a vast expertise about minimizing trauma in vaginal birth. Third, the possibility exists that the hand techniques used in this setting might improve patient outcomes in other places where clinicians have higher base- line rates of childbirth lacerations. This difference between the present study and the study of Albers et al. may be related to the difference in the study setting, where the setting in the present study performing an episiotomy is a routine intervention nearly for all primiparous births.

The results of the present study showed no significant difference between study and control groups regarding, mode of delivery, duration of the second stage, and baby birth weight. This result is in accordance with the findings of Dahlen $e t$ al.'s trial (2007). ${ }^{[29]}$ Their results had revealed that no significantly different between the groups in relation to the duration of second stage, birth position, mode of birth, and infant birth weight.

The need for pain relief during the second stage of labor in the present study was noticed to be highly significantly decreased among the study group than the control group (see Table 4). In this respect Hobbs (2001) emphasized that the perineal warm packs are used in the belief that they reduce perineal trauma but equally importantly that they increase comfort during the second stage which in turn reducing the requirement for pain relief after birth. ${ }^{[42]}$ This finding is in harmony with that of Ahmad and Turky (2010) who found that women in the experimental group requested pain relief less frequently than the control group with statistical significant difference. ${ }^{[31]}$

\section{Conclusion}

Based on the findings of this study, it can be concluded that second stage perineal warm compresses had better effects on perineal pain and perineal outcome, specifically:

Perineal pain intensity-measured by VAS-was decreased after the application of perineal warm compresses among the study group. Whereas it was increased among the control group after the application traditional care.

Behavioral pain responses measured by Behavioral Pain Rating Scale as presented by tense muscles, restlessness, grimacing and patient sounds was decreased after the application of second stage perineal warm compresses among study group.

The second stage perineal warm compresses had prodigious significant effect on decreasing episiotomy rate, vaginal tear, perineal tear, and need to repair as well as lowering degree of perineal tear.

\section{Recommendations}

Based on the findings of this study, a special attention should be given for raising the awareness of women as well as care providers about perineal warm compresses for management of the second stage of labor. Specifically, the following recommendations are suggested:

ISSN 1925-4040 E-ISSN 1925-4059 
(1) Perineal warm compresses should be incorporated into perineal pain relief and perineal maintaining options available to women during second stage of labor. It can be encouraged as a beneficial non medical approach in obstetric practice, since it was found to be well-accepted by laboring women.

(2) The curricula of basic nursing/midwifery education as well as continuing education should entail the perineal warm compresses for management of the second stage of labor.

(3) In services training program should be periodically monitored to maternity nurses to upgrade their knowledge and skills about uses and importance of applying warm compresses on the perineum during second stage of labor to help them perform their role effectively.

(4) Further researches are also recommended:

A. The effect of warm compresses on other pains encountered during the maternity cycle.

B. Assessment of laboring women's satisfaction with the use of perineal warm compresses for management of second stage of labor.

C. Replication of the present study at different sittings and among different subjects.

\section{ACKNOWLEDGEMENTS}

We are very grateful to the women who participated in the study. We are also extremely grateful to the midwives and obstetricians at the labor and delivery unit of National Medical Institution in Damanhour Hospital, for their enthusiastic support and encouragement, for without them, this trial would never have been completed.

\section{Conflicts of InTEREST Disclosure}

The authors declare that there is no conflict of interest.

\section{REFERENCES}

[1] Sönmez Y. Doğum öncesi bakım hizmetleri (The Prenatal Care Services). Sürekli Tıp Eğitimi Dergisi, in Turkish. 2007; 16: 9-12

[2] Albers L, Borders N. Minimizing Genital Tract Trauma and Related Pain Following Spontaneous Vaginal Birth. Journal of Midwifery \& Women's Health. 2007; 52: 246-253. PMid:17467591 http://dx.doi.org/10.1016/j.jmwh.2006.12.008

[3] Dönmez S, Kavlak O. Effects of Prenatal Perineal Massage and Kegel Exercises on the Integrity of Postnatal Perine. Health. 2015; 7: 495-505. http://dx.doi.org/10.4236/health.2015.74059

[4] Zhou F, Wang X, Li J, et al. Hyaluronidase for reducing perineal trauma (Review). The Cochrane Collaboration. John Wiley \& Sons; 2014.

[5] Nkwabong E, Kouam L. Episiotomies during Deliveries of Singletons in Cephalic Presentation: The Incidence can be Reduced. The Journal of Obstetrics and Gynecology of India. 2012; 62(6): 641-643. PMid:24293840 http://dx.doi .org/10.1007/s13224-012-0 207-z

[6] Pitangui A, Carvalho N, Siqueira C, et al. Occurrence and factors associated to the practice of episiotomy. J Nurs UFPE on line. Recife. 2014; 8(2): 257-63.

[7] Lone F, Sultan A, Thakar. Obstetric pelvic floor and anal sphincter injuries. The Obstetrician \& Gynaecologist. 2012; 14: 257-66. http://dx.doi.org/10.1111/j.1744-4667.2012.00133.x

[8] Cunningham F, Leveno K, Bloom S, et al. Williams Obstetrics. 24rd ed. New York: McGraw-Hill Medical. 2014; 433-452.

[9] Groutz A, Cohen A, Gold R, et al. Risk factors for severe perineal injury during childbirth: A case-control study of 60 consecutive cases. Colorectal Dis. 2011; 13(8): e216-9. PMid:21689311 http://dx.doi.org/10.1111/j.1463-1318.2011.02620.x

[10] Smith L, Price N, Simonite V, et al. Incidence of and risk factors for perineal trauma: A prospective observational study. BMC Pregnancy and Childbirth. 2013; 13(59): 1-9. http://dx. doi.org/10.1186 /1471-2393-13-59

[11] Williams A, Herron-Marx S, Carolyn H. The prevalence of enduring postnatal perineal morbidity and its relationship to perineal trauma. Midwifery (Elsevier). 2007; 23(4): 392-403. PMid:17196714 http://dx.doi.org/10.1016/j.midw.2005.12.006

[12] Kalichman L. Perineal Massage to Prevent Perineal Trauma in Childbirth. IMAJ. 2008; 10: 531-533. PMid:18751635

[13] Willer H, Aabakke A, Krebs L. The effect of primary delivery of the anterior compared with the posterior shoulder on perineal trauma: A study protocol for a randomized controlled trial. Trials. 2014; 15: 291. PMid:25047001 http://dx.doi.org/10.1186/1745-621 5-15-291

[14] Voldner N, Frøslie K, Haakstad L, et al. Birth complications, overweight, and physical inactivity. Acta Obstetricia et Gynecologica. 2009; 88: 550-555. PMid:19277916 http://dx.doi.org/10.10 $80 / 00016340902818162$

[15] Dahlen H. Reduction of perineal trauma and improved perineal comfort during and after childbirth: The Perineal Warm Pack Trial. Sydney: 2007.

[16] Sanders J, Peters T, Campbell R. Techniques to reduce perineal pain during spontaneous vaginal delivery and perineal suturing: A UK survey of midwifery practice. Midwifery. 2005; 21(2): 154160. PMid:15878430 http://dx.doi.org/10.1016/j.midw . 20 04.12 .003

[17] Rozita R, Sussan S, Yiong Huak C, et al. A Comparison of the "Hands-Off" and "Hands-On" Methods to Reduce Perineal Lacerations: A Randomised Clinical Trial. The Journal of Obstetrics and Gynecology of India. 2014; 64(6): 425-429. PMid:25489147 http://dx.doi.org/10.1007/s13224-014-0535-2

[18] Petrocnik P, Marshall J. Hands-poised technique: The future technique for perineal management of second stage of labor? A modified systematic literature review. Midwifery. 2015; 31: 274279. PMid:25467599 http://dx.doi .org/10.1016/j .midw . 20 14.10 .004

[19] Zare O, Pasha H, Faramarzi M. Effect of perineal massage on the incidence of episiotomy and perineal laceration. Health. 2014; 6: 10-14. http://dx.doi.org/10.4236/health.2014.61003 
[20] Lydon-Rochelle M. Perineal outcomes and nurse-midwifery management. Journal Nurse Midwifery. 1995; 40: 13-18. http://dx.doi .org/10 . 1016/0091-2182(94)00086-L

[21] Albers L, Anderson D, Cragin L, et al. Factors related to perineal trauma in childbirth. Journal of Nurse Midwifery. 1996; 41: 269-276. http://dx.doi.org/10.1016/0091-2182(96)00042-0

[22] Murphy P, Feinland J. Perineal Outcomes in a Home Birth Setting Birth. 1998; 25(4): 226-234. http://dx.doi.org/10.1046/j.1 523-536X.1998.00226.x

[23] Musgrove H. Perineal preservation and heat application during the second stage of labor. Midwifery Today E-News. 1999; 1(33).

[24] Aasheim V, Nilsen A, Lukasse M, et al. Perineal techniques during the second stage of labor for reducing perineal trauma (Review). The Cochrane Collaboration. John Wiley \& Sons. 2012.

[25] Vaziri F, Farahmand M, Samsami A, et al. The effects of warm perineum compress during the second phase of labor on first-birth outcomes. Modern Care. 2014; 11(1): 28-36.

[26] McCaffery M, Pasero C. Numeric Pain Rating Scale. Pain: Clinical Manual, 2nd ed. Mosby; 1999. 67 p.

[27] Mateo O, Krenzischeck D. A pilot study to assess the relationship between behavioral manifestations and self-report of pain in postanesthesia care unit patients. Journal of Post Anesthesia Nursing. 1992; 7(1): 15-21. PMid:1531235

[28] Araújo N, Oliveira S. The use of liquid petroleum jelly in the preven tion of perineal lacerations during birth. Rev Latino-am Enfermagem Maio-junho. 2008; 16(3): 375-81. http://dx.doi.org/10.1590 /s0104-11692008000300007

[29] Dahlen H, Homer C, Cooke M, et al. Perineal outcomes and maternal comfort related to the application of perineal warm packs in the second stage of labor: a randomized controlled trial. Birth. 2007; 34(4): 282-290. PMid:18021143 http://dx.doi.org/10.1111/j.152 3-536X. 2007.00186.x

[30] Behmanesh F, Pasha H, Zeinalzadeh M. The Effect of Heat Therapy on Labor Pain Severity and Delivery Outcome in Parturient Women. Iranian Red Crescent Medical Journal. 2009; 11.
[31] Ahmad E, Turky H. Effect of applying warm perineal packs during the second stage of labor on perineal pain among primiparous women. AAMJ. 2010; 8(3): 1-26.

[32] Mamuk R, Gençalp N. Effect of warm application to the perineum in vaginal labor on perineal integrity and pain. International Journal of Human Sciences. 2013; 10(2): 48-66.

[33] Porth C. Pathophysiology-Concepts of altered health states. 3rd ed. Philadelphia: J.B. Lippincott Company. 1990. PMid:2270310

[34] Craven R, Hirnle C. Fundamentals of nursing. Human health and function 4th ed. Philadelphia: Lippincott Willams \& Wilkans Co. 2003; 1018-19.

[35] Simkin P, Ancheta R. The labor progress handbook. Michigan: Blackwell Science. 2003.

[36] Ward S, Hisley S. Maternal-child nursing care optimizing outcomes for mothers, children, and families. Philadelphia: F.A. Davis Company; 2009. $405 \mathrm{p}$.

[37] Hastings-Tolsma M, Vincent D, Emeis C, et al. Getting through birth in one piece. Protecting the perineum. Medicine Clinics of North (MCN). 2007; 32 (3): 158-164.

[38] Dahlen H, Homer C, Cooke M, et al. "Soothing the ring of fire": Australian women's and midwives experiences of using perineal warm packs in the second stage of labor. Midwifery. 2009; 25: e39e48. PMid:18031878 http://dx.doi.org/10.1016/j.midw. 20 07.08 .002

[39] Mohamed M, Mohamed S, Gonied A. Comparative Study between Two Perineal Management Techniques Used to Reduce Perineal Trauma during 2nd Stage of Labor. Journal of American Science. 2011; 7(11): 228-232.

[40] Dahlen H, MComm N, Priddis H. Severe perineal trauma is rising, but let us not overreact. Midwifery. 2015; 31: 1-8. PMid:25440297 http://dx.doi.org/10.1016/j.midw.2014.09.004

[41] Albers L, Sedler K, Bedrick E, et al. Midwifery Care Measures in the Second Stage of Labor and Reduction of Genital Tract Trauma at Birth: A Randomized Trial. J Midwifery Women's Health. 2005; 50(5): 365-372. PMid:16154062 http://dx.doi.org/10.1016 /j.jmwh. 2005.05.012

[42] Hobbs L. The Best Labour Possible. Oxford Books. 2001. 